\title{
META ANALISIS MEDIA PEMBELAJARAN IPA SMP/MTS BERBASIS VIRTUAL REALITY
}

\author{
Siti Rahmawati ${ }^{*}$, Putri Anggun Paradia ${ }^{2}$, Faiq Makhdum Noor ${ }^{3}$ \\ Tadris IPA, Institut Agama Islam Negeri Kudus \\ Email:1.rw756304@gmail.com
}

\begin{abstract}
ABSTRAK
Pembelajaran menggunakan media Virtual Reality sangat sederhana dan dapat diakses secara mudah melalui banyak platform contohnya di Smartphone. Media pembelajaran Virtual Reality diimplementasikan terhadap siswa SMP. Hal yang menarik dari media Virtual Reality yaitu bisa diakses dengan mudah dan dimana saja contohnya pada website YouTube, sehingga siswa dapat belajar dan memiliki peluang yang sangat besar, khususnya pengembangan pada potensi keilmuwan dalam dunia pendidikan.Penelitian ini menjawab permasalahan bagaimana kemampuan analisis media pembelajaran IPA dengan menggunakan media Virtual Reality di jenjang SMP. Metode penelitian yang digunakan pada penelitian ini adalah meta analisis. Secara keseluruhan penelitian ini membuktikan adanya perbedaan kemampuan analisis pada aspek membedakan, mengorganisasikan, dan mengatribusikan antara siswa yang menggunakan media Virtual Reality dengan yang menggunakan media presentasi dalam mata pelajaran IPA di jenjang SMP/MTS. Dalam situasi pandemi sistem pembelajaran daring adalah solusi dari permasalahan COVID-19. Oleh sebab itu penting adanya media pembelajaran untuk siswa, salah satu media yang dapat dilakukan pendidik khususnya pada jenjang SMP/MTS adalah media pembelajaran virtual reality menjadi solusi agar pendidikan di Indonesia tidak mengalami penurunan karena adanya pamdemi COVID-19.
\end{abstract}

Kata Kunci: Media Pembelajaran, Virtual Reality, Kemampuan Analisis.

\section{ABSTRACT}

Easily through many platforms, for example on smartphones. Virtual Reality learning Learning using Virtual Reality media is very simple and can be accessed media is implemented for junior high school students. The interesting thing about Virtual Reality media is that it can be accessed easily and anywhere, for example on the YouTube website, so that students can learn and have enormous opportunities, especially the development of scientific potential in the world of education. This research answers the problem of how the ability to analyze science learning media by using Virtual Reality media at the junior high school level. The research method used in this research is meta-analysis. Overall, this study proves that there are differences in analytical skills in the aspects of distinguishing, organizing, and attributing students who use Virtual Reality media and those who use presentation media in science subjects at the SMP / MTS level. In a pandemic situation, the online learning system is the solution to the COVID-19 problem. Therefore it is important to have learning media for students, one of the media that educators can do especially at the SMP / MTS level is virtual reality learning media which is a solution so that education in Indonesia does not experience a decline due to the COVID-19 pandemic. 


\section{Keywords: Virtual Reality, Learning Media, Analysis Ability.}

\section{PENDAHULUAN}

Dunia pendidikan memiliki peranan penting dalam kehidupan suatu bangsa. Perkembangan belajar, pemanfaatan ilmu dan teknologi dalam proses pembelajaran dapat membantu peran guru dalam menyampaikan materi ajar terlebih lagi dalam materi ajar fisika, kimia, maupun biologi. Penggunaan media pembelajaran dalam proses pengajaran sangat dianjurkan untuk mempertinggi kualitas pembelajaran (Mansyur\&Akbar Iskandar,2017). Pendidikan merupakan usaha sadar dan sistematis, yang dilakukan orang-orang yang diserahi tanggung jawab untuk mempengaruhi siswa agar mempunyai karakter dan tabiat sesuai dengan cita-cita pendidikan. Fisika, kimia, biologi merupakan ilmu yang termuat dalam rumpun IPA. Teori-teori yang dipelajari dalam ilmu IPA tidak hanya bersifat kongkrit, tetapi ada teori yang bersifat abstrak. Contohnya pada materi fisika yang teorinya bersifat abstrak sangat sulit untuk diajarkan ke peserta didik secara langsung. Fakta-fakta yang terdapat pada materi fisika juga tidak seluruhnya bisa secara nyata ditampilan oleh pendidik sehingga hal ini membuat peserta didik sulit dalam menguasai teori dan media pembelajaran yang diberikan oleh pendidik. Media pembelajaran adalah alat ukur bantu yang digunakan oleh guru/tenaga pendidik dalam proses pembelajaran. Menurut Sanjaya (2013) media bukan hanya berupa alat bantu atau bahan saja, akan tetapi hal-hal lain yang memungkinkan siswa dapat memperoleh pengetahuan layaknya media animasi tentang ipa. Anitah (2010) menyatakan bahwa media pembelajaran adalah setiap media yang di dalamnya terkandung informasi yang dapat dikomunikasikan kepada orang lain. Secara khusus media pembelajaran memiliki fungsi dan kegunaan (Surata, n.d.).

Fungsi media dalam proses belajar mengajar yaitu untuk meningkatkan rangsangan peserta didik dalam kegiatan minat belajar. Media apabila dipahami secara garis besar adalah manusia, materi atau kejadian,membangun kondisi yang membuat siswa mampu memperoleh pengetahuan, keterampilan atau sikap, dalam pengertian ini guru, buku teks, dan lingkungan sekolah merupakan media. Secara lebih khusus, pengertian media dalam proses belajar mengajar cenderung diartikan sebagai alat-alat grafis, photografis atau elektronis untuk menangkap, memproses, dan menyusun kembali informasi visual atau verbal.

Sedangkan menurut Nasution. menuliskan media pembelajaran menurut (1) Gagne bahwa media pembelajaran sebagai komponen sumber belajar di lingkungan siswa yang dapat merangsang siswa untuk belajar, (2) Briggs media pembelajaran adalah wahana fisik yang mengandung materi pelajaran dan (3) Schramm media pembelajaran adalah teknik pembawa informasi atau pesan pembelajaran. Bagi tenaga pengajar memiliki peranan yang sama dengan sumber belajar lainnya. Perkembangan sumber belajar untuk mata pelajaran IPA dalam memahami materi fisika,kimia,biologi di jenjang SMP masih sangat sedikit dan kurang variatif. Padahal saat ini dengan adanya kurikulum 2013 siswa dituntut untuk belajar secara mandiri,apalagi pada kondisi pandemic covid 19 saat ini, yang mengharuskan para peserta didik belajar di rumah.

Hal ini mendukung implementasi dari tujuan pendidikan nasional yang tertuang dalam Undang-Undang (UU) No. 20 Tahun 2003 Pasal 3 menyebutkan pendidikan nasional berfungsi mengembangkan kemampuan dan membentuk watak serta peradaban bangsa yang bermartabat dalam rangka mencerdaskan kehidupan bangsa, bertujuan untuk berkembangnya 
potensi peserta didik agar menjadi manusia yang beriman dan bertakwa kepada Tuhan Yang Maha Esa, berakhlak mulia, sehat, berilmu, cakap, kreatif, mandiri, dan menjadi warga negara yang demokratis serta bertanggung jawab (Departemen Pendidikan Nasional) (Septiani, n.d.).

Dalam amanat Undang-Undang tersebut menyiratkan bahwa pendidikan sebaiknya dapat membentuk generasi Indonesia yang cerdas, kreatif, berkualitas, inovatif dan proaktif terhadap perkembangan zaman khusunya pada perkembangan terknologi era revolusi industri 4.0. Media pembelajaran selalu mengikuti perkembangan teknologi, mulai dari teknologi cetak, audio visual, komputer sampai teknologi gabungan antara teknologi cetak dengan komputer. Saat ini media pembelajaran hasil gabungan teknologi cetak dan komputer dapat diwujudkan dengan teknologi Augmented Reality (AR) dan Virtual Reality (VR). Teknologi VR merupakan integrasi elemen digital yang ditampilkan secara nyata (data real-world) dan mengikuti keadaan lingkungan yang ada di dunia nyata serta dapat diterapkan pada perangkat mobile. Virtual reality sangat membantu dalam mensimulasikan sesuatu yang sulit untuk dihadirkan secara langsung dalam dunia nyata. Kelebihan utama dari virtual reality adalah pengalaman yang membuat user merasakan sensasi dunia nyata dalam dunia maya (Kartika Dewi; 2020).

Media pembelajaran yang digunakan pada saat pembelajaran seharusnya disesuaikan dengan perkembangan teknologi informasi yang terjadi saat ini. Salah satu media pembelajaran yang bisa diterapkan dalam proses pembelajaran yang sesuai dengan perkembangan revolusi industri 4.0 adalah media pembelajaran berbasis Virtual Reality. Virtual Reality merupakan media yang berfungsi untuk menampilkan proyeksi gambar dari layar suatu smartphone menjadi lebih jelas dan nampak nyata. Dengan majunya teknologi yang semakin canggih, bidang pendidikan juga memerlukan hasil perkembangan tersebut. Misalnya Virtual Reality selain untuk hiburan, tampilan video dan audio secara virtual yang juga bisa digunakan sebagai media pembelajaran, khususnya dalam bidang ipa. Dengan menggunakan Virtual Reality, dapat membuat peserta didik lebih cepat mengingat, memahami dan fokus terhadap materi.

Meta analisis adalah suatu teknik yang digunakan untuk merangkum temuan dua penelitian atau lebih dengan tujuan untuk menggabungkan, meninjau dan meringkas penelitian sebelumnya. selain itu dengan menggunakan metaanalisis berbagai pertanyaan dapat diselidiki berdasarkan data yang telah ditemukan dari hasil penelitian sebelumnya yang telah dipublikasikan dan salah satu syarat yang diperlukan dalam melakukan meta analisis adalah pengkajian terhadap hasil-hasil penelitian yang sejenis. Meta analisis merupakan analisis kuantitatif dan menggunakan sejumlah data yang cukup banyak serta menerapkan metode statistik dengan mempraktekkannya dalam mengorganisasikan sejumlah informasi yang berasal dari sampel besar yang fungsinya untuk melengkapi maksud-maksud lainnya untuk mengorganisasikan dan menggali informasi sebanyak mungkin dari data yang diperoleh, serta sebagai suatu teknik ditujukan untuk menganalisis kembali hasil-hasil penelitian yang diolah secara statistik berdasarkan pengumpulan data primer.

Perbedaan artikel ini dengan artikel lainnya ialah terdapat pada keunikan atau kekhasan pada penelitian yang sedang kita teliti yaitu terletak pada jenis Virtual Reality yang digunakan untuk menunjang proses pembelajaran pada masa pandemi covid 19 saat ini. Media Virtual reality yang kita teliti ialah berupa aplikasi Phet, Crocodile Chemistry, yaitu 
berupa aplikasi media pembelajaran yang menunjang peserta didik dalam belajarnya terutama dalam belajar mata pelajaran IPA, karena aplikasi ini dirancang secara menarik yaitu berupa animasi dan gambar yang menarik, sehingga pengguna tidak merasa bosan ketika mempelajari aplikasi tersebut dan juga memudahkan bagi peserta didik dalam memahami suatu pelajaran tersebut (Fadil Abdillah 2018).

\section{METODE}

Penelitian ini merupakan pengembangan dari sebuah teknologi yang membuat pengguna atau suatu user dapat berinteraksi dengan liangkungan yang ada dalam dunia maya yang disimulasikan oleh computer sehingga pengguna merasa berada di dalam lingkungan tersebut. Penelitian ini bertujuan untuk mengetahui perkembangan metode virtual reality dalam dunia pendidikan di masa pamdemi COVID-19. Waktu pelaksanaan penelitian ini dimulai pada bulan Oktober sampai pada bulan Desember tahun 2020. Penelitian ini melalui media WhatsApp dengan Subjek Guru IPA di kalangan SMP maupun SMA.

Penelitian Ini mengacu pada metode meta analisis dimana penelitian ini bersifat deskriptif dan lebih cenderung pada data analisis yang diperoleh dari hasil wawancara dengan berbagai subjek serta observasi, maupun literasi pada penelitian terdahulu. Data hasil penelitian ini mencakup hasil jawaban dari para guru yang mengampu mata pelajaran IPA, serta hasil uji coba dan implementasi perangkat berupa virtual reality pada proses pembelajaran mata pembelajaraan IPA. Data dikumpulkan dengan teknik observasi (keterlaksanaan pembelajaran) dan wawancara dengan menggunakan aplikasi whatsapp.

Penelitian ini merupakan penelitian meta analisis terhadap hasil penelitian media pembelajaran IPA berbasis Virtual Reality. Penelitian meta analisis ini merupakan penelitian yang menggunakan data sekunder berupa data-data dari hasil penelitian sebelumnya. Penelitian ini dapat disebut sebagai penelitian yang bersifat ex post facto yang berbentuk survey dan analisis kepustakaan terhadap penelitian yang telah dilakukan. Penelitian ini akan dilaksanakan di lingkungan sekolah terutama pada sekolah tingkat menengah SMP/MTs. Instrumen penelitian ini hanya dokumentasi yaitu untuk memperoleh data tentang efektifitas penggunaan media pembelajaran berbasis virtual reality. Sedangkan teknik pengumpulan data dikumpulkan melalui teknik dokumentasi. Teknik ini dimaksudkan untuk memperoleh data tentang siswa. Teknik analisis data yang digunakan adalah Analisis deskritif dan untuk menilai apakah satu hasil meta-analisis 'robust' (relatif stabil terhadap perubahan) perlu dilakukan uji sensitivitas, antara lain dengan cara membandingkan hasil penelitian. Bila hasilnya sama atau hampir sama, dapat disimpulkan bahwa variasi antar-penelitian tidak begitu penting pada set data tersebut(Syafi'ie, n.d.).

\section{HASIL DAN PEMBAHASAN}

Bab ini memuat gagasan peneliti yang terkait dengan apa yang telah dilakukan dan apa yang telah diamati serta dianalisis. Hasil dan pembahasan penelitian pada tahap ini secara garis besar akan menjelaskan dalam dua bagian utama. Bagian pertama hasil pemetaan data responden yang telah dilakukan. Bagaian kedua merupakan hasil analisis pengolahan data yang disesuaikan dengan masalah yang telah dirumuskan sebelumnya.

Jumlah judul artikel jurnal yang dianalisis dalam penelitian ini yaitu 7 buah judul dengan rincian: 
1. Model Inquiry Based Learning Untuk Pembelajaran IPA Dan FISIKA sebanyak 1 judul

2. Meta-Analisis Media Pembelajaran pada Pembelajaran Biologi sebanyak 1 judul

3. Pengembangan Video Pembelajaran Berbasis Virtual Reality sebanyak 1 judul

4. Pemanfaatan Media 3 Dimensi Berbasis Virtual Reality Untuk Meningkatkan Minat Dan Hasil Belajar IPA sebanyak 1 judul

5. Pengaruh Penggunaan Media Virtual Reality Terhadap Kemampuan Analisis Siswa Pada Pembelajaran Ilmu Pengetahuan Alam Kelas VIII Sekolah Menengah Pertama sebanyak 1 judul

6. Aplikasi Berbasis Virtual Reality Untuk Mendukung Proses Pembelajaran Organ Pencernaan Manusia sebanyak 1 judul

7. Pelatihan Pemanfaatan Media Pembelajaran Berbasis Virtual Reality untuk GuruGuru IPA sebanyak 1 judul

Elaborasi lebih lanjut dari masing-masing judul di atas dijelaskan secara rinci pada bagian berikut :

1. Model Inquiry Based Learning Untuk Pembelajaran IPA Dan FISIKA

Model pembelajaran IPA dan Fisika yang ditulis oleh program studi TADRIS IPA IAIN KUDUS terdiri atas Model virtual reality Berdasarkan Materi Pembelajaran, Model virtual reality Berdasarkan Bahan Ajar dan Media Pembelajaran, Model virtual reality Berdasarkan Jenis dan Desain, Hasil Penelitian dengan Model virtual reality.

2. Meta-Analisis Media Pembelajaran pada Pembelajaran Biologi

Meta analisis Media Pembelajaran pada pembelajaran biologi yang ditulis oleh program studi TADRIS IPA IAIN KUDUS terdiri atas distribusi sampel artikel, distribusi jenis penelitian, distribusi tingkat pendidikan, distribusi jenis media, dan distribusi materi.

3. Pengembangan Video Pembelajaran Berbasis Virtual Reality

Pengembangan video pembelajaran berbasis virtual reality yang ditulis oleh program studi TADRIS IPA IAIN KUDUS terdiri atas tahap pengumpulan informasi, tahap perencanaan desain pengembangan tahap pengembangan produk, uji produk yang dilakukan oleh ahli dan guru.

4. Pemanfaatan Media 3 Dimensi Berbasis Virtual Reality Untuk Meningkatkan Minat Dan Hasil Belajar IPA

Pemanfaatan media 3 dimensi virtual reality yang ditulis oleh program Studi TADRIS IPA IAIN KUDUS terdiri atas desain, pengembangan produk, implementasi dan evaluasi produk, Keefektifan Media 3 Dimensi (3D) Berbasis Virtual Reality Terhadap Hasil Belajar, dan Keefektifan media 3 Dimensi (3D) Berbasis Virtual Reality Terhadap Minat Siswa.

5. Pengaruh Penggunaan Media Virtual Reality Terhadap Kemampuan Analisis Siswa Pada Pembelajaran Ilmu Pengetahuan Alam Kelas VIII Sekolah Menengah Pertama 
Pengaruh penggunaan media virtual reality terhadap kemampuan analisis siswa yang ditulis oleh program studi TADRIS IPA IAIN KUDUS terdiri atas uji normalitas kelas eksperiment, uji normalitas kelas kontrol, dan uji hipotesis.

\section{Aplikasi Berbasis Virtual Reality Untuk Mendukung Proses Pembelajaran Organ} Pencernaan Manusia

Aplikasi berbasis virtual reality yang ditulis oleh program studi TADRIS IPA IAIN KUDUS terdiri atas Development (Pembuatan Aplikasi), tampilan antar muka, dan Implementation (Pengujian).

7. Pelatihan Pemanfaatan Media Pembelajaran Berbasis Virtual Reality untuk Guru-Guru IPA(Asikin 2019).

Pemanfaatan media pembelajaran berbasis virtual reality untuk guru IPA yang ditulis oleh program studi TADRIS IPA IAIN KUDUS terdiri atas pelatihan pemanfaatan media pembelajaran berbasis Virtual Reality untuk guru-guru IPA di Kota Tanjungpinang terlaksana dengan lancar melalui ketiga tahapan kegiatan. Peserta pelatihan sangat tertarik dan antusias dalam mengikuti kegiatan pelatihan. Peserta juga memperoleh pengetahuan, keterampilan dan termotivasi untuk menggunakan media pembelajaran berbasis Virual Reality. Peserta memberikan respon positif terhadap kegiatan pelatihan dan bisa menerapkan media pembelajaran yang bervariasi dalam proses pembelajaran sehingga dapat meningkatkan kualitas pembelajaran.

\section{Model Inquiry Based Learning Untuk Pembelajaran IPA Dan FISIKA}

Hasil meta-analisis yang dilihat dari segi kecocokan materi dengan model menunjukkan beberapa materi cocok menggunakan model IBL. Salah satunya yaitu materi suhu dan kalor yang kaya akan percobaan. Percobaan yang dilakukan seperti pada sub perpindahan kalor, asas Black, peristiwa perubahan wujud zat dan lain-lain. Pada tingkat pemahaman, siswa mampu menyatakan masalah dengan kata-katanya sendiri dan mampu memberi contoh. Hal tersebut cocok dengan model IBL yang membantu peserta didik untuk dapat aktif, kolaboratif dan kreatif dalam pembelajaran. Pada umumnya model IBL sangat membantu proses pembelajaran yang berbasis praktikum. Langkah-langkah dalam model IBL mengarahkan peserta didik untuk dapat menemukan sendiri dan melakukan penyelidikan. Oleh sebab itu materi-materi yang cocok menggunakan model IBL adalah materi yang memiliki sub topik untuk melakukan eksperimen dan akan sangat membantu untuk meningkatkan keterampilan peserta didik (Dewi, n.d.).

Bahan ajar merupakan salah satu perangkat pembelajaran yang dapat menunjang keberhasilan dalam proses pembelajaran. Bahan ajar juga berperan dalam membantu guru menyajikan materi serta mengarahkan peserta didik dalam mencapai tujuan pembelajaran. Bahan ajar adalah segala bentuk bahan yang digunakan untuk membantu guru/instruktur dalam melaksanakan kegiatan belajar mengajar. Salah satu bahan ajar yang disarankan oleh kurikulum 2013 adalah lembar kerja siswa (LKS). LKS dan laboratorium virtual memiliki tujuan yang sama dalam proses pembelajaran. Tujuannya antara lain membantu tercapainya kompetensi pengetahuan sikap dan keterampilan peserta didik. Hal ini sejalan denga model pembelajaran inkuiri yang dapat membantu peserta didik mencapai 
kompetensi keterampilan. Kompetensi keterampilan dicapai dengan melakukan praktikum nyata maupun tidak nyata. Setelah melakukan praktikum peserta didik dapat memahami konsep-konsep yang baik sehingga dapat menunjang kompetensi pengetahuan peserta didik. LKS dapat berfungsi sebagai penguatan, juga sebagai pengayaan dan dasar pemberian umpan balik kepada peserta didik.

LKS berfungsi sebagai alat untuk memberi pengayaan terhadap hasil belajar, karena pekerjaan yang dibuat dapat memperluas dan memperkaya materi pembelajaran yang dipelajari. Pelaksanaan praktikum yang dibantu oleh media dan bahan ajar tentunya juga dapat mengarahkan sikap peserta didik kepada sikap ilmiah. Sebagian besar dari penelitian pendidikan yang dilakukan cenderung melihat hasil belajar peserta didik atau tingkat ketercapaian kompetensi pembelajaran. Empat dari sepuluh artikel yang dipilih secara acak mengemukakan variabel penelitian berupa hasil belajar peserta didik. Enam artikel lainnya merupakan variasi dari variabel-variabel penelitian yang lain. Penerapan model IBL dapat meningkatkan hasil belajar peserta didik. Hal tersebut karena fasefase pada model IBL menuntun peserta didik untuk menemukan dan melakukan penyelidikan sehingga proses pembelajaran menjadi lebih bemakna. Ratarata post-test peserta didik meningkat dan persentasi kemampuan secara klasikal juga meningkat. Hal ini sejalan dengan penelitian sebelumnya. Oleh karena itu model IBL disimpulkan dapat meningkatkan hasil belajar peserta didik dalam memahami konsep Fisika maupun konsep IPA.

Pengembangan bahan ajar berbasis model IBL masih minim dalam penelitian pendidikan. Meta analisis ini memperlihatkan bahwa dari 10 sampel artikel hanya terdapat satu artikel pengembangan LKS berbasis model IBL. Oleh sebab itu untuk peneliti kedepannya diharapkan dapat lebih banyak mengembangkan bahan ajar maupun perangkat pembelajaran berbasis model IBL (Nieuwenstein, n.d.).

2. Meta-Analisis Media Pembelajaran pada Pembelajaran Biologi

Penelitian yang sudah masuk sebagai artikel jurnal merupakan penelitian pengembangan media pembelajaran biologi. penelitian merupakan penelitian eksperimen yang menguji kefeektifan penggunaan media pembelajaran biologi. Sisanya merupakan penelitian deskriptif. Penelitian media pembelajaran biologi lebih banyak menggunakan metode $\mathrm{R} \& \mathrm{D}$ karena metode ini memungkinkan peneliti menghasilkan produk media dengan mempertimbangkan berbagai aspek antara lain: analisis kebutuhan pengguna (peserta didik dan dosen), pendapat ahli isi, media, maupun desain sehingga diharapkan diperoleh produk media pembelajaran yang tepat guna. Pengujian kelayakan produk untuk R \& D sebaiknya tidak hanya pada sebatas pendapat ahli tetapi sampai pada end user (peserta didik) dalam kuantitas yang lebih banyak sehingga data yang diperoleh lebih mewakili populasi. Produk hasil R \& D yang hanya di uji kelayakannya oleh ahli lebih lanjut dapat dilakukan penelitian selanjutnya berupa penelitian tindakan, deskriptif, ataupun menjadikan produk bahan eksperimen pembelajaran di dalam kelas.

Tingkat Pendidikan SMA/MA dan SMP/MTs menunjukkan adanya pengaruh positif dari media pembelajaran terhadap hasil belajar, pada PT belum ada data pendukung untuk perhitungan effect size. Selain itu, penelitian tentang media pembelajaran biologi paling banyak dilakukan pada tingkat SMA/MA yaitu 64,29\%, disusul penelitian di tingkat SMP/MTs sebanyak 21,43\%. Data pengujian media pembelajaran menunjukkan lebih baik pada SMP/MTs masuk kategori efek tinggi $(1,00)$ dan implementasi media pembelajaran pada SMA/MA menunjukkan efek sedang $(0,62)$. Sedangkan, implementasi pada 
perguruan tinggi belum ada data hasil pengujian kuantitatif. Peserta didik SMP/MTs merupakan remaja yang penuh dengan rasa ingin tahu yang berkembang penelaranya dari konkret menuju kemampuan penalaran abstrak sehingga media pembelajaran bagi SMP/MTs akan lebih efektif.

Penelitian dengan data yang mendukung perhitungan effect size menunjukkan pengaruh positif media, kecuali pada media berbasis android. Hal tersebut dapat disebabkan karena penerapan media tersebut pada materi biologi kelas 10 (sepuluh) yang begitu banyak dan rancangan media yang kurang ramah pengguna. Tabel 4 menunjukkan jenis media pembelajaran yang paling digunakan adalah media audio visual/video dan multimedia yaitu masing-masing sebanyak $23,43 \%$. Hal tersebut disebabkan karena dalam materi biologi lebih banyak materi berupa teori, konsep, proses, dan beberapa perhitungan sederhana yang tentunya lebih mudah dijelaskan dalam bentuk media audio visual misalnya sistem organ, ekologi, dan genetika. Multimedia lebih mudah digunakan dengan melibatkan proses uji konsep setelah suatu materi dipelajari oleh peserta didik, yang dapat dibuat menggunakan adobe flash. Hal tersebut diperkuat dengan efect size tertinggi ditunjukkan pada penelitian yang mengimplementasikan media pembelajaran biologi berupa multimedia yaitu 2,00 masuk kategori effect size dengan pengaruh yang tinggi. Multimedia merupakan media pembelajaran yang di dalamnya mengandung berbagai media baik audio, visual, dan atau kuis/tes yang umumnya ditampilkan secara interaktif dan ramah pengguna. Multimedia memudahkan peserta didik dalam memahami konsep materi maupun mengecek penguasaan materinya. Sehingga, memberikan peserta didik belajar mandiri dan mengevaluasi diri apakah perlu mengulang pembelajaran atau sudah cukup dengan pemaham konsep yang dimilikinya. Salah satu multimedia interaktif yang kreatif dikembangkan oleh Indrawan, dkk (2019) yaitu multimedia interaktif yang mendukung pembelajaran offline maupun online yang selanjutnya didefinisikan sebagai Blended Learning Media (BLM) yang agak berbeda dengan Nurhikmah, dkk (2018) yang lebih menunjuk BLM adalah media pendukung blended learning. Penerapan media pembelajaran biologi khususnya yang berbasis digital harus memperhatikan ketersediaan peralatan memadai seperti laboratorium computer/laptop, ruangan media, alat proyektor (infokus), kertas bidang infokus dan adanya sumber arus listrik.

Media pembelajaran sangat membantu proses pembelajaran biologi karena tidak semua materi biologi dapat kita pelajari dari lingkungan kita, apalagi kalua sekolah tidak memiliki fasilitas laboratorium yang lengkap khususnya media berbasis IT. Minimal dengan media pembelajaran peserta didik dapat ditunjukkan torso, gambar dan atau video terkait materi biologi. Pada fasilitas yang lebih modern pembelajaran biologi dibantu dengan media yang berbasis online, yang dapat diakses oleh peserta didik dimanapun dan kapanpun mereka ingin belajar, tanpa harus membawa buku. Media pembelajaran memberikan peluang peserta didik untuk belajar lebih mandiri, melakukan repetisi setelah evaluasi, dan melakukan pengkayaan pemahaman dengan mengeksplor lebih jauh materi yang dipelajari. Hal tersebut menyebabkan penerapan media pembelajaran biologi dapat meningkatkan hasil belajar peserta didik (Paldam 2015). Proses pembelajaran biologi sering dihadapkan pada materi yang tidak dapat divisualisasikan secara langsung sehingga sulit dipahami peserta didik .Beberapa yang sulit divisualisasikan secara langsung antara lain anatomi dan fisiologi manusia, jaringan, sel, evolusi, genetika, taksonomi dan asalusul mahluk hidup. Kesulitan ini yang kemudian diatasi dengan menggunakan media pembelajaran Selanjutnya dinyatakan, media pembelajaran merupakan unsur yang sangat 
penting dalam pembelajaran. Salah satu fungsi utama media pembelajaran adalah sebagai alat bantu mengajar yang turut memotivasi, mempengaruhi iklim, kondisi, dan lingkungan belajar yang ditata dan diciptakan oleh guru (Rufaidah 2008).

\section{Pengembangan Video Pembelajaran Berbasis Virtual Reality}

Tahap Pengumpulan Informasi Pada tahap ini peneliti mengobservasi bagaimanakah pemahaman siswa pada video pembelajaran konvensional yang masih berformat dua dimensi. Tahap ini diawali dengan mengobservasi kelas, meninjau penggunaan video pembelajaran dengan pemahaman siswa terhadap materi yang disampaikan, Ketersediaan Sarana dan prasarana untuk menunjang video pembelajaran Berbasis VR. Langkah selanjutnya adalah meninjau standar isi, hal ini dilakukan untuk mencari kesesuaian materi dengan Standar Kompetensi (SK) dan Kompetensi Inti (KI). Hal tersebut dilakukan untuk menentukan materi yang akan dibawakan dalam video pembelajaran berbasis VR. Berdasarkan tahapan tersebut didapatkan dua materi video pembelajran yang akan dikembangkan yaitu Materi Tentang Gunung berapi dan kehidupan bawah laut. Setelah ditemukan materi yang akan dikembangkan, selanjutnya ialah tahap penyesuaian materi dengan perangkat VR.

Tahap perencanaan desain pengembangan Pada tahap ini konsep dari pengembangan video pembelajaran berbasis VR mulai dibuatkan timeline pengembangan. Tahap kedua ini terdiri dari pembuatan kisi-kisi instrumen penelitian yang menjadi kriteria penilaian pengembangan. Kisikisi instrumen yang telah selesai dibuat lalu dikembangkan menjadi instrumen penelitian. Instrumen penelitian yang akan digunakan adalah lembar uji coba ahli, lembar observasi, angket dan pedoman wawancara. Lembar uji coba digunakan untuk mengetahui kelayakan video pembelajaran berbasis Virtual Reality berdasarkan penilaian ahli. Lembar observasi, angket dan pedoman wawancara digunakan untuk mengetahui respon dan tanggapan guru serta siswa mengenai penggunaan video pembelajaran berbasis Virtual Reality di dalam kelas. Validasi instrumen dilakukan oleh dosen pembimbing. Pembelian beberapa perlengkapan VR dan penunjang VR, pembelian disesuaikan dengan spesifikasi yang dibutuhkan, agar dapat bekerja secara maksimal. Melakukan pemasangan aplikasi AAA video Player pada perangkat 5 yang akan digunakan.

Tahap pengembangan produk Pada tahap ini dilakukan pembuatan produk video pembelajaran berbasis Virtual Reality. Langkah-langkah yang dilakukan yaitu; 1) Membuat Time Line. Time Line dibuat dengan tujuan mempermudah dalam penyusunan media dan untuk menentukan tahap pengembangan selanjutnya, agar bagian-bagian dari video pembelajaran dapat berjalan dengan baik. 2) Time Line lalu dijadikan acuan dalam pengembangan video pembelajaran dengan memperhatikan aspek kemudahan, warna, komposisi dan kejelasan Informasi; 3) pada tahap ini mulai melakukan pengeditan video, penyesuaian resolusi, pembetulan angel, dan melakukan penyesuaan video dengan aplikasi pemutar video dan 4) Setelah langkah diatas telah selesai maka file video pembelajaran berbasis VR di simpan dalam memori internal Smartphone.

Uji produk yang dilakukan oleh ahli dan Guru Tahap uji coba ahli ini dilakukan agar video pembelajaran yang dikembangkan dapat diketahui kelayakannya berdasarkan penilaian ahli. Uji coba video pembelajaran VR dilakukan oleh ahli yang berkompeten dalam bidang media pembelajaran interaktif(Beni Pribadi 2019). 
4. Pemanfaatan Media 3 Dimensi Berbasis Virtual Reality Untuk Meningkatkan Minat Dan Hasil Belajar IPA

Hasil validasi ahli materi dan ahli media menunjukkan materi serta media 3 dimensi berbasis virtual reality sangat sesuai dan sangat layak digunakan dalam pembelajaran. Sehingga media 3 dimensi berbasis virtual reality yang dikembangkan ini bersifat valid, praktis dan efektif; Respon kelompok eksperimen ingin menggunakan media 3D dan hasil belajar siswa kelas $\mathrm{V}$ lebih baik dibandingkan dengan sekolah kelompok kontrol sehingga media 3D berbasis virtual reality dinyatakan efektif; 3) Produk media 3 dimensi (3D) berbasis virtual reality dikemas dapat bentuk keping CD atau flasdisk.

Tahap implementasi dievaluasi keefektifannya dalam meningkatkan minat dan hasil belajar siswa. Hasilnya terdapat peningkatkan minat dan hasil belajar siswa secara signifikan. Nilai rata-rata semula 49,55 diperoleh capaian rata-rata sebesar 82,08. Produk media 3D disusun berdasarkan tahap perencanaan. Seperti penelitian Mary Michelle Bowen (2018) menunjukkan terdapat perbedaan skor signifikan antara siswa yang menggunakan virtual reality dari Google Expeditions dalam pembelajaran dengan siswa yang menggunakan pengajaran tradisional segi motivasi maupun prestasi siswa. Penelitian Sulistyowati, dkk (2017), berhasil mengembangkan aplikasi teknologi 3D virtual reality pada pembelajaran matematika tingkat SD untuk mengetahui kevalidan dan kelayakan diperoleh pencapaian kepuasan terhadap aplikasi teknologi 3D virtual reality.

Penelitian terdahulu sejalan dengan hasil penelitian pengembangan media 3 dimensi (3D) oleh peneliti, bahwa media 3 dimensi (3D) berbasis virtual reality layak digunakan dalam pembelajaran IPA pada siswa kelas 5 SD di Kecamatan Tasikmadu. Edgar Dale (dalam Anitah.S, 2008) meyakini semakin konkrit siswa mempelajari bahan pelajaran maka pesan atau informasi yang diperoleh akan tersampaikan dengan baik. Teori ini sesuai dengan media 3 dimensi (3D) berbasis virtual reality yang dikembangkan, bahwa media yang konkrit mampu merangsang pikiran, perasaan, perhatian dan minat. Sesuai penelitian Mike Tz-Yauw Lin (2017), bahwa media teknologi virtual reality 3D mampu mengefektifkan pembelajaran secara signifikan. Media 3 dimensi (3D) berbasis virtual reality terbukti sangat efektif dalam menyampaikan informasi yang serupa/memvisualisasikan materi yang selama ini sulit diterangkan secara konvensional, selain itu dapat meningkatkan minat belajar dan tujuan pembelajaran tercapai dengan baik(Mulyasa 2007).

5. Pengaruh Penggunaan Media Virtual Reality Terhadap Kemampuan Analisis Siswa Pada Pembelajaran Ilmu Pengetahuan Alam Kelas VIII Sekolah Menengah Pertama

Dalam pelaksanaannya peneliti menggunakan dua kelas yaitu, satu kelas sebagai kelas eksperimen dan satu kelas sebagai kelas kontrol. Pada kedua kelas tersebut, membahas materi pelajaran yang sama yaitu mengenai pokok materi Tata Surya. Perbedaannya terletak pada perlakuan yang diberikan pada masingmasing kelas. Pelaksanaan penelitian ini menggunakan instrumen berbentuk soal uraian objektif dengan jumlah 10 butir soal.

Pada kelas eksperimen soal pretest diberikan kepada 40 orang siswa. Pada hasil pretest kelas eksperimen diperoleh skor total 934 dengan rata-rata skor 23,4 dan skor terendah 9 serta skor tertinggi skor 33. Sementara untuk hasil posttest kelas eksperimen diperoleh skor total 1314 dengan rata-rata 32,9 dan skor terendah 18 serta skor tertinggi yaitu 40. Kemudian untuk kelas kontrol dengan 40 orang siswa pada hasil pretest diperoleh skor total 796 dengan rata-rata 19,9 skor terendah 11 serta skor tertinggi skor 29, 
sementara untuk hasil posttest kelas kontrol diperoleh skor total 1015 dengan rata-rata 25,4 skor terendah 16 dan skor tertinggi yaitu 33 (Djamarah, .S.B. dan Zain 2006).

6. Aplikasi Berbasis Virtual Reality Untuk Mendukung Proses Pembelajaran Organ Pencernaan Manusia

Pembuatan aplikasi diawali dengan membuat aset-aset yang diperlukan dalam aplikasi seperti objek 3D berupa organ tubuh manusia, papan, informasi, dan kotak jalan kemudian tekstur dan animasi. Berikut beberapa proses pembuatan aset-aset dalam aplikasi VR Organ Pencernaan beserta aplikasi yang digunakan, antara lain : Aset Objek 3D Pembuatan aset-aset objek 3D seperti organ tubuh manusia, papan, informasi, dan kotak jalan menggunakan aplikasi Blender. Objek 3D antara lain : 1. Mulut yang mencakup gigi, lidah, dan faring. 2. Kerongkongan/Esofagus. 3. Lambung yang mencakup kardiak, fundus, badan lambung, dan pilorus. 4. Usus halus yang mencakup duodenum, jejunum, ileum. 5. Usus besar yang mencakup usus buntu, sekum, kolon, dan rektum. 6. Hati 7. Kantung empedu 8. Pakreas 9. Terdapat papan yang mempunya fungsi berbeda beda, seperti papan animasi, papan informasi, dan papan kembali. 10. Terdapat kotak yang berfungsi membuka informasi organ dan tempat player bergerak.

Tampilan Antarmuka Tampilan antarmuka merupakan tampilan dari aplikasi yang akan dioperasikan oleh pengguna dimana tampilan dibuat berdasarkan rancangan pada bab sebelumnya. Halaman Utama Aplikasi Halaman ini merupakan halaman pertama saat palikasi dijalankan. Terdapat 4 sisi yaitu bagian depan (judul), kanan (tutorial), belakang (menu mode), dan kiri (objek panah). Halaman Menu Mode Roller Coaster (RC) Pada halaman ini terdapat 4 sisi yaitu bagian depan (Menu Mode), kanan (Objek Panah), kiri (Objek Panah), dan belakang (Kembali). Halaman Organ Detail Halaman Organ Detail berisi objek 3D organ yang telah dipilih. Terdapat beberapa kotak biru sebagai tempat pengguna bergerak, terdapat papan untuk menganimasikan organ, terdapat informasi seputar organ, dan juga kotak kembali ke menu mode sebelumnya. Berikut beberapa tampilan dari Organ Detail.

Implementation (Pengujian) Pengujian dilakukan dengan memberikan pembelajaran kepada siswa kelas VIII di SMP Muhammadiyah Pakem. Sebelum melakukan pembelajaran, penulis berdiskusi dengan guru untuk menentukan tempat dan waktu untuk melakukan pembelajaran serta berapa jumlah siswa 44 yang akan mencoba aplikasi "VR Organ Pencernaan". Setelah itu, sebanyak 3 siswa diambil dari masing-masing kelas VIII yang berjumlah 4 kelas untuk menjadi responden. Jadi jumlah responden sebanyak 12 siswa. Alat-alat yang digunakan dalam memberikan pembelajaran berupa satu laptop, satu smartphone, dan satu VR Box. Pada saat pelaksanaan menggunakan VR Box, siswa diberikan waktu selama 10 menit. Penulis memberikan pengarahan kepada siswa sebelum dan saat menggunakan VR Box. Beberapa siswa ada yang tahu cara menggunakan VR Box, namun belum mengerti cara menggunakannya. Setelah menggunakan VR Box, siswa diberikan kuesioner tentang aplikasi "VR Organ Pencernaan". Setelah selesai pembelajaran, guru-guru yang mendampingi siswa pada saat pelaksaanan ikut mencoba menggunakan VR Box (Duffy dan Roehler 1989). 
7. Pelatihan Pemanfaatan Media Pembelajaran Berbasis Virtual Reality untuk Guru-Guru IPA

Tim pengabdian dalam melaksanakan program PkM pertama kali yang dilakukan adalah menjalin komunikasi dengan mitra. Mitra dalam PkM ini adalah Musyawarah Guru Mata Pelajaran (MGMP) IPA SMP di Kota Tanjungpinang. Tim pengabdian melakukan komunikasi dan bersilaturahmi dengan pengurus MGMP IPA yang di sambut langsung oleh ketua MGMP IPA Kota Tanjungpinang yaitu Bapak Drs. Arifurahman yang berlokasi di SMP Negeri 5 Tanjungpinang. Kegiatan silaturahmi ini bermaksud untuk melakukan diskusi awal terkait pengabdian yang dilaksanakan. Dari hasil diskusi di peroleh kesepakatan tentang jadwal pelaksanaan kegiatan pengabdian kepada masyarakat.

Pelaksanaan kegiatan pengabdian kepada masyarakat dihadiri oleh peserta pelatihan yaitu guru-guru IPA yang tergabung dalam MGMP IPA Kota Tanjungpinang yang berjumlah 40 orang. Selain guru, juga dihadiri Koordinator Pembina dan Pengawas SMP Kota Tanjungpinang. Hasil yang diperoleh dari kegiatan pengabdian kepada masyarakat adalah terlaksananya ketiga tahapan pelaksanaan pengabdian. Tahap pertama pelatihan adalah tentang pengenalan macam-macam media pembelajaran yang digunakan sesuai dengan perkembangan Revolusi Industri 4.0 salah satu media yang digunakan adalah media pembelajaran berbasis Virtual Reality. Setelah melalui pelatihan tahap 1 ini diharapkan guru telah mengetahui macam-macam media pembelajaran yang sesuai dengan perkembangan teknologi informasi di era Revolusi Industri 4.0 yang siap diaplikasikan dalam pembelajaran. Pelatihan tahap 2 dengan materi tentang pelatihan penggunaan media pembelajaran berbasis Virtual Reality dalam pembelajaran. Setelah pelatihan tahap 2 selesai dilaksanakan, guru pada lokus pengabdian dibimbing dalam penggunaan VR Box, aplikasi-aplikasi dan video yang mendukung dalam Virtual Reality. Pelatihan tahap 3 dilakukan di akhir periode pengabdian, tujuan dilakukannya tahap ketiga ini untuk mengkonfirmasi hasil dan kemajuan peserta kegiatan pengabdian (Sanjaya 2012)

Dalam pelaksanaan kegiatan diperoleh beberapa faktor yang menjadi tantangan yaitu jaringan internet di sekolah yang kurang memadai. Hal ini diatasi oleh pelaksana kegiatan untuk menyediakan jaringan internet melalui provider data seluler yang kemudian digunakan oleh peserta melalui mode tethering smartphone. Hanya saja, kondisi ini kemudian akan menjadi tantangan bagi pihak sekolah untuk bisa menyediakan akses internet yang lebih baik dan luas untuk guru dan siswa. Kondisi berikutnya adalah sulit mengatur jadwal kegiatan dikarenakan padatnya jadwal guru di sekolah. Selain itu, belum tersedianya sarana berupa VR box atau google VR disekolah, hal ini dapat diatasi oleh tim pelaksana pengabdian dengan menyediakan sarana google VR dalam proses pelatihan, kondisi ini juga menjadi tantang pihak sekolah agar bisa menyediakan sarana dalam menunjang penggunaan media pembelajaran berbasis Virtual Reality yang sesuai dengan perkembangan teknologi dan informasi di era Revolusi Industri 4.0 (Sugiyono,2013).

\section{PENUTUP}

Berdasarkan hasil meta-analisis pada penelitian ini disimpulkan bahwa berbagai penelitian mengenai model media pembelajaran IPA SMP/MTs berbasis virtual reality meningkatkan hasil belajar peserta didik. Media dan bahan ajar yang digunakan untuk menunjang terlaksananya model IBL/VR yang sering digunakan adalah virtual laboratorium dan Lembar kerja siswa. Materi yang dominan digunakan dalam penelitian model Virtual 
Reality adalah materi yang membutuhkan eksperimen dalam penemuan konsep seperti suhu dan kalor. Sebagian besar penelitian yang dilakukan adalah penelitian eksperimen, beberapa penelitian pengembangan dan penelitian tindakan kelas. Oleh sebab itu model Virtual reality sangat bagus dan lebih sempurna untuk digunakan jika media dan bahan ajar LKS /media pembelajaran yang digunakan adalah virtual laboratorium dan menggunakan jenis penelitian yang sesuai dengan tujuan penelitian.

\section{DAFTAR PUSTAKA}

Asikin, Nurul. 2019. "Pelatihan Pemanfaatan Media Pembelajaran Berbasis Virtual Reality Untuk Guru-Guru IPA Kota Tanjungpinang." Jurnal Anugerah 1 (2), https://ojs.umrah.ac.id/index.php/anugerah/article/view/1606/895

Dewi, Ramdhan. n.d. "PENGEMBANGAN VIDEO PEMBELAJARAN BERBASIS VIRTUAL REALITY DI SEKOLAH DASAR ISLAM MULTIPLUS AR RAHIIM." Skripsi Universitas Muhamadiyah Surakarta,http://eprints.ums.ac.id/57064/19/Naspub-libraryums-ramdhan.pdf

Djamarah, .S.B. dan Zain, A. 2006. "Strategi Belajar Mengajar." Jakarta: Rineka Cipta.

Duffy dan Roehler. 1989. "Improving Classroom Reading Instruction." New York: Radom Hause.

Fadil Abdillah. 2018. "PENGARUH PENGGUNAAN MEDIA VIRTUAL REALITY TERHADAP KEMAMPUAN ANALISIS SISWA PADA PEMBELAJARAN ILMU PENGETAHUAN ALAM KELAS VIII SEKOLAH MENENGAH PERTAMA, EDUTCEHNOLOGIA"2 (1), http://repository.upi.edu/47512/

Kartika Dewi. 2020. "PEMANAFAATAN MEDIA 3 DIMENSI BERBASIS VIRTUAL REALITY UNTUK MENINGKATKAN MINAT DAN HASIL BELAJAR IPA SISWA KELAS V SD." Jurnal Pendidikan 21 (1), https://www.jurnal.ut.ac.id/index.php/jp/article/view/732

Mansyur. 2017. "META ANALISIS KARYA ILMIAH MAHASISWA PENELITIAN DAN EVALUASI PENDIDIKAN." Jurnal Scientific Pinisi 3 (1), http://ojs.unm.ac.id/index.php/pinisi/article/download/4384/2529

Mulyasa. 2007. "Kurikulum Tingkat Satuan Pendidikan.” Bandung: Remaja Rosdakarya.

Nieuwenstein. n.d. "A Meta-Analysis and Large-Scale Replication Attempt of the Unconscious Thought Advantage. Judgment and Decision Making" 10 (1).

Paldam, M. 2015. "Meta-Analysis in a Nutshell: Techniques and General Findings MetaAnalysis in a Nutshell: Techniques and General Findings. Economics: The OpenAccess, Open-Assessment." https://doi.org/10.5018/economicsejournal.ja.2015-11

Pribadi, Beni. A. 2019. "Model Desain Sistem Pembelajaran.” Jakarta: Dian Rakyat.

Rufaidah. 2008. "Kolaborasi Dan Graf Komunikasi Artikel Ilmiah Peneliti Bidang Pertanian : Studi Kasus Pada Jurnal Penelitian Dan Pengembangan Pertanian Serta Indonesian Journal of Agricultural Science Vivit Wardah Rufaidah.” Jurnal Perpustakaan Pertanian 17 (1).

Sanjaya, W. 2012. "Perencanaan Dan Desain Sistem Pembelajaran.” . Jakarta: Kencana. Septiani, Tri. n.d. "META-ANALISIS MODEL INQUIRY BASED LEARNING UNTUK PEMBELAJARAN IPA DAN FISIKA PADA ABAD.” Pillar of Physics Education, 12 (4), http:/lejournal.unp.ac.id/students/index.php/pfis/article/download/7910/3724 
Sugiyono, 2013, "Metode Penelitian Kuantitatif Kualitatif Dan R\&D," Bandung: Alfabeta.

Surata, I K. n.d., "Meta-Analisis Media Pembelajaran Pada Pembelajaran Biologi." Journal of Education Technology 4 (1), https://ejournal.undiksha.ac.id/index.php/JET/article/view/24079

Syafi' ie, Muhammad. n.d. “APLIKASI BERBASIS VIRTUAL REALITY UNTUK MENDUKUNG PROSES PEMBELAJARAN ORGAN PENCERNAAN MANUSIA.”, https://dspace.uii.ac.id/bitstream/handle/123456789/11883/13523237-

Muhammad\%20Syafiie\%20Nurbadi-

Laporan\%20Skripsi.pdf? sequence $=2 \&$ isAllowed $=y$ 